\title{
Green Chemistry Synthesis of Nano-Hydroxyapatite : Effect of Natural Stabilisers on $\mathbf{C a} / \mathbf{P}$
}

\author{
Sreedevi Nimishakavi ${ }^{*}$, V. Madhusudhan Rao², T. N. Aishwarya ${ }^{3}$, A. K. Singh ${ }^{4}$ \\ 1,2Vignan's Foundation for Science, Technology \& Research, Guntur, Andhra Pradesh, India \\ ${ }^{3}$ Student in SFM, KOMVUX, Sweden \\ ${ }^{4}$ Defence Metallurgical Research Laboratory, Hyderabad, Telangana, India \\ "Corresponding author: E-mail : nsdrn2013@gmail.com
}

\begin{abstract}
Article Info

Volume 8, Issue 4

Page Number: 382-389

Publication Issue :

July-August-2021

\section{Article History}

Accepted : 16 Aug 2021

Published: 20 Aug 2021

Present work described the effect of natural stabilizers on $\mathrm{Ca} / \mathrm{P}$ on naturally synthesised and Eco-friendly Nano-HAP powders.Nano- powders were preparedemploying wet chemical precipitation method by adjusting $\mathrm{Ca} / \mathrm{P}$ between 1.5 to2.2,using different Natural Stabilisers (NSs)such as Rice Water (RcW), Soya Milk (SM), Tea Decoction (TD), Tulsi Leaves (TL), Soya Leaves (SL), Rose Petals (RP), Spinach Leaves (SpL), Gum Kondagogu (GKg) and Aloe Vera (AlV)as precursors. The $\mathrm{pH}$ of the powders was varying from 8.1 to 12.8.In this paper, the average crystallite sizes of the samples, $\mathrm{pH}$, therate of reaction, initial temperature and $\mathrm{Ca} / \mathrm{P}$ of synthesised powders are reported.

Keywords : Nano-HAP, Wet-chemical precipitation, Natural Stabilisers (NSs), $\mathrm{pH}, \mathrm{Ca} / \mathrm{P}$
\end{abstract}

\section{INTRODUCTION}

Hydroxyapatite (HAP) chemically an inorganic component of bone and teeth, with stoichiometric formula $\mathrm{Ca}_{10}(\mathrm{OH})_{2}\left(\mathrm{PO}_{4}\right)_{6}$ and $\mathrm{Ca} / \mathrm{P}=1.67[1,2]$.It has been reported that the application of micro sized HAP to bone regeneration is not satisfactory, due to its size. In addition to that,treatment duration using micro sized HAP is very long. Thus, the nano-HAP synthesis has taken a great lead in dental and orthopaedic treatments. In recent years, development in applying Nano biology approach to Hydroxyapatite is based on the concept that the mineral atoms arranged in a crystal structure of HAP can be substitutedand / or incorporated by the other mineral atoms.

The basic elements of crystals composed of atomic minerals in certain geometric patternsand their relationship to the bone cell bioactivity have opened opportunities for nano-HAP applications in dental care, orthopaedics and treatment of osteoporosis. The behaviour of mineral atoms in the substitution have a better impact on the management of its treatment[3]. Significant research efforts have been bestowed to develop the preparation and morphological changes of HAP. HAP Powders with various morphologies have been synthesized by means of solid-state reaction [4,5], sol-gel method [6,7],template direct 
method[8,9],hydrothermal method[10,11]and micro emulsion [12,13] or emulsion technique [14]. However, the most convenient and commonmethod to prepare HAP powders is the wet chemical precipitation method.

Present efforts are accordingly focused on preparing nano-powders of HAP using wet chemical precipitation method under normal conditions of pressure and temperature, investigating the changes in its $\mathrm{pH}$, rate of reaction, initial temperature and $\mathrm{Ca} / \mathrm{P}$. Nano- HAP powders have been prepared using Natural Stabilisers (NSs) as precursors.

\section{Experimental Section}

\subsection{Materials}

Calcium Hydroxide $\mathrm{Ca}(\mathrm{OH}) 2 \mathrm{M}=74.09 \mathrm{~g} / \mathrm{mol}$ (Merk Life SciencePvt. limited, Mumbai, India), Ammonia solution $\mathrm{NH} 4 \mathrm{OH}, \mathrm{M}=17.03 \mathrm{~g} / \mathrm{mol}$ (Merk Life Science Pvt. limited, Mumbai, India), Orthophosphoric Acid $\mathrm{H}_{3} \mathrm{PO}_{4}$ (Merk Life Science Pvt. limited, Mumbai, India) and $15 \mathrm{ml}$ of solutions made out of nine Natural Stabilisers such as Rice Water (RcW), Soya Milk (SM), Tea Decoction (TD), Tulsi Leaves (TL), Soya Leaves (SL), Rose Petals (RP), Spinach Leaves (SpL), Gum Kondagogu (GKg) and Aloe Vera (Alv).

\subsection{Synthesis}

Nano-HAP has been synthesised by a wet chemical precipitation method following the reaction proposed by Yagai and Aoki as indicated by Bouyer et al.[15].

$10 \mathrm{Ca}(\mathrm{OH})_{2}+6 \mathrm{H}_{3} \mathrm{PO}_{4} \rightarrow \mathrm{Ca} 10\left(\mathrm{PO}_{4}\right)_{6}(\mathrm{OH})_{2}+18 \mathrm{H}_{2} \mathrm{O}(1)$ [16].

The shape, size and specific surface area of the nanoHAP particles obtained by this method are very sensitive to the reactant addition rate and to the reaction temperature. This determines the purity of the synthesized nano-HAP and is linked strongly to the $\mathrm{pH}$ obtained at the end of the synthesis and to the suspension stabilisation [17].
$10 \mathrm{Ca}(\mathrm{OH})_{2}+6 \mathrm{H}_{3} \mathrm{PO}_{4}+20 \quad \mathrm{NH} 4 \mathrm{OH} \rightarrow \mathrm{Ca}_{10}\left(\mathrm{PO}_{4}\right)_{6}$ $(\mathrm{OH})_{2}+20 \mathrm{NH}_{3}+38 \mathrm{H}_{2} \mathrm{O}(2)$

Ammonium Hydroxide is used as a leaving agent or acidity regulator in food and drug administration and is generally recognised as a safe reagent. Its $\mathrm{pH}$ controlling abilities make it an effective antimicrobial agent. Aqueous ammonia is an excellent acid neutraliser [18].

\section{3. Present approach for synthesis}

The modification of nano-HAP is developed using natural stabilisers has resulted in homogeneous precipitation. The wet chemical precipitation method offers molecular level mixing of these NSs that are capable of improving chemical homogeneity of resulting nano-HAP to an agreeable extent. NanoHAP synthesis requires calcium to phosphorous molar ratio 1.67. A number of combinations of NSs were employed during this wet-chemical precipitation.

Recent trends towards use of plant based natural products demand synthetic additives with natural ones.Soymilk are used as a nutrient alternative for natural milk. Fortified soymilk has 109 calories consisting of $5 \mathrm{~g}$ Fats, $0.5 \mathrm{~g}$ Saturated fats, $6 \mathrm{~g}$ sugar, $7 \mathrm{~g}$ proteins $30 \%$ calcium, $30 \%$ vitamin $\mathrm{D}$. This data is collected from the USDA Nutrient Database. Soymilk contains same amount of calcium as milk. It is the best alternative for people who do not consume milk due to allergies and lactose intolerance or cultural and religious reasons. Soymilk is a good source of organic product for bone health [19, 20].

RcW is a healthy solution which contains chock full of vitamins, minerals and amino acids. It is also a powerful antioxidant that contains anti-inflammatory properties [21]. The rice grain consists of $13.57 \%$ moisture and $0.92 \%$ of fat and has highest fibre contents of $0.85 \%$ and carbohydrate content $82.7 \%$. It contains Calcium, Zinc and Iron and is dependent on quality of rice. It is a non-inflammatory substance and works as a dispersant to control the agglomeration process [22]

Tea is the most widely consumed human beverage and rich in flavonoids, which causes significant 
endothelium dependent vasodilatation. Tea decoction contains antioxidants, reduces the risk of heart attacks, helps to protect bones, decreases systolic blood pressure, cholesterol and it also acts as an antimicrobial agent. It has vitamin $\mathrm{K}, \mathrm{B} 2$, Minerals sodium, potassium, calcium magnesium copper and manganese. It has micronutrients carbohydrates and proteins [23].

Plant extracts are regarded as one of the most promising natural reducing agents, as metabolites, proteins and co-enzymes that help to synthesise metal and metal nano-particles. Gum Kondagogu has antibacterial properties that can stabilise nanoparticles. It also has natural compounds such as vitamins, proteins, peptides and sugars which provide suitable reducing and surface agents for the nano particle synthesis and stabilization [24].

Tulsi leaves has high amount of anti-microbial, hypoglycemic, immune-modulators, anti-stress, analgesic anti pyritic, anti- inflammatory antiulcergenic, anti hypertensive, radio-protective, antitumour, anti-bacterial properties. Dental plaque most commonly implicates microorganisms in the causation of periodontal disease. To reduce their levels in the oral cavity is one of the rationales for the prevention and control of periodontal disease. Tulsi leaves reduce spermatogenesis by retarding Sterols cells active [25]. It has an ability to protect the DNA from dangerous radiations. Fresh leaves of this medicinal plant and its essential oils have shown more antibacterial properties [26]. Scientific literature survey yields no documentation on Ocimum Sanctum against the preparation of dental materials nano-HAP. Therefore, a study has been conducted by preparing nano-HAP powders using these NSs. The main aim of present study is to determine the activity of NSs on the properties of nano-HAP powders.

Soya Leaves (SL) or dill weed is an aromatic herb with delicate feathery green leaves. The health benefits of SL include its ability to boost digestion as well as providing relief from insomnia, menstrual and respiratory disorders. It is also good for oral care and can be a powerful boost for immune system. It also provides protection from your bone degradation. It has anti-inflammatory and analgesic properties, which can protect against arthritis. Soya Leaves (SL) are good mouth and breathe fresheners. Apart from that the essential oils in it are germicidal, anti-oxidant and disinfectant in nature. Due to these properties, they help in minimizing infections in the mouth and their antioxidant minimizes the damage caused by face radicals to gums and teeth as well. Calcium content of SL protects from bone loss as well as loss of bone density [27, 28].

Aloe-vera (Alv) is a plant that has unique therapeutic properties. It is an oldest medicinal plant and is the most applied medicinal plant worldwide. Studies have convincingly demonstrated that the Alv treatment can accelerate the healing of mouth ulcers. A patch of Alv gel applied to the area is remarkably effective in reducing the size of the ulcers and it is an ingredient in different mouth washes. When used as a mouth rinse, pure Alv juice is just as effective as a reducing dental plaque agent in present day health and hygiene conditions that are associated with mouth and teeth. Tooth decay diseases of the gum are very common dental health problems [29].

Spinach (Spinacia Oleracea) is a leafy green vegetable that is considered as a very healthy food as it is loaded with nutrients and antioxidants. It is an extremely nutrient rich Leafy vegetable. It packs high amounts of carotenes, vitamin $\mathrm{C}$, vitamin $\mathrm{K}$, folic acid and calcium [30, 31].

Rose is from a woody perennial plant belonging to the genus Rosa in the family Rosacea, known for its smell and beauty. It is used as a medicinal herb because of its anti-bacterial and anti-fungal activity. The parts of the plant, especially the petals, have high anti-oxidant property that helps in curing many health ailments [32]. Captivatingly, the previous research reviews have laid foundation for its medicinal use and its effect on human health, in different areas. The Rose 
Petals (RP) extract was found to exhibit a better antifungal and anti-bacterial activity against periodontal pathogens namely, periodontal gingivitis and periodontal intermediate. The sensitivity of $\mathrm{RP}$ dilution in water is $\sim 100 \mu \mathrm{g} / \mathrm{mL}$ [33]. It's anti-bacterial and anti-fungal properties could be due to the presence of several-bacterial and anti-fungal properties of ethanol extract of RP against periodontal pathogens $[34,35]$.

Nano-HAP powders were synthesized using nine NSs such as Rice Water (RcW), Soya Milk (SM), Tea Decoction (TD), Tulsi Leaves (TL), Soya Leaves (SL), Rose Petals (RP), Spinach Leaves (SpL), Gum Kondagogu (GKg) and Aloe Vera (AlV). These NSs are identified as good sources of Calcium or Phosphorus, antioxidants andanti-inflammatory natural products containing rich protein. $15 \mathrm{~mL}$ of freshly prepared Natural Stabiliser solutions are used in the modification method of nano-HAP synthesis.

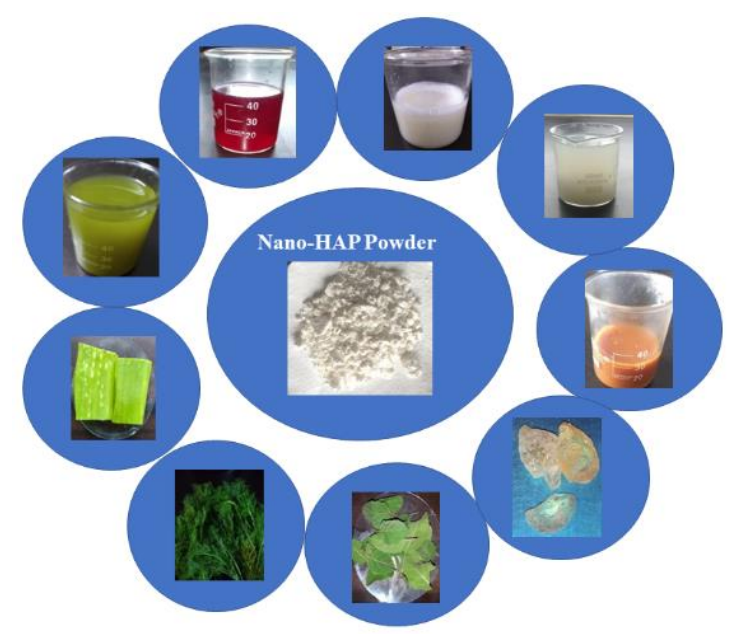

Figure 1 : Overall picture of synthesis of nano-HAP using different Natural Stabilisers

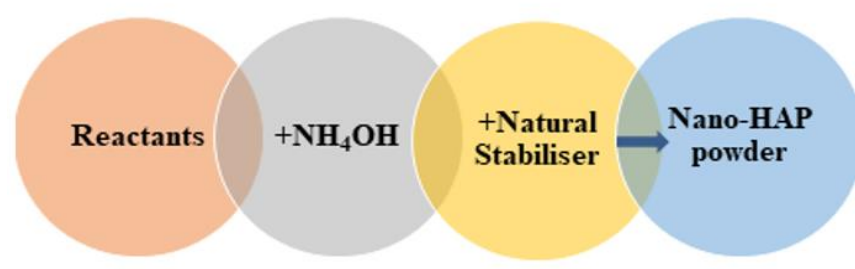

Figure 2: Reaction process while synthesising nanoHAP using NSs
Nano-HAP powders have been prepared by adding NSs as precursors under normal atmospheric pressure and temperature by stirring, using magnetic stirrer. Crystallization starts after adding $\mathrm{NH}_{4} \mathrm{OH}$.

\section{$10 \quad \mathrm{Ca}(\mathrm{OH})_{2}+6 \quad \mathrm{H}_{3} \mathrm{PO}_{4+} \quad 20 \quad \mathrm{NH}_{4} \mathrm{OH}+\quad \times(\mathrm{NS}) \rightarrow$} $\mathrm{Ca} 10\left(\mathrm{PO}_{4}\right)_{6}(\mathrm{OH})_{2} \times(\mathrm{NS})+20 \mathrm{NH}_{3}+38 \mathrm{H}_{2} \mathrm{O}$

Where $x$ in equation (3), is $15 \mathrm{ml}$ of NS used in the modification process.

The objective of this study is to investigate the $\mathrm{Ca} / \mathrm{P}$ ratio of nano-HAP powders synthesised using different NSs by wet-chemical precipitation method. These nano-HAP powders may have potential biomedical applications.

\section{Results and discussion}

\subsection{Effect of NS on $\mathrm{pH}$ and Initial temperature:}

Using the bio mimetic coating method, in contrast to the other coating techniques, biologically active agents can be added to the super saturated solutions and gradually be co-precipitated with the calcium phosphate crystals, forming a layer on the metal implants [36, 37]. This creates the possibility of incorporating an antibiotic within the bio mimetic coating and releasing it at a controlled rate, therefore, preventing local post-surgical infection [38].

Initial $\mathrm{pH}$ values influence the balance of ions in the solution. It has been noticed from the literature that different $\mathrm{pH}$ values on the concentration of $\mathrm{OH}^{-}$ could influence the concentration of $\mathrm{Ca}^{2+}, \mathrm{PO}_{4}{ }^{3-}$, $\left(\mathrm{HPO}_{4}\right)^{2-}$ and so on. High concentration of $\mathrm{OH}^{-}$could promote the process of precipitation of nano-HAP. Presently the growth units of $\mathrm{pH}$ can be due to addition of NS. During the crystallisation process, the reaction temperature is another dependent factor on crystal morphology. It influences the crystal phase and crystal morphology and also the degree of crystallinity. The effect of NS on its $\mathrm{pH}$ and the initial temperature is given in Table 1.The $\mathrm{pH}$ above 10.00 is very much pertinent for dental or orthopaedic materials. Among the synthesised nano-HAP powders, 
it is observed that the $\mathrm{pH}$ of powders synthesised with $\mathrm{SpL}$ and RP as NSs are falling below 10.00. The $\mathrm{pH}$ of all the other nano-HAP powders' is above 10.00. The relationship between $\mathrm{pH}$ and Initial Temperature of the reactions taken place (while synthesising the nano-HAP powders) is shown in Figure 3.

Table 1: Effect of NS on $\mathrm{pH}$ and initial Temperature

\begin{tabular}{|l|l|l|l|}
\hline $\begin{array}{l}\text { S. } \\
\text { No. }\end{array}$ & NS at 15ml & $\mathrm{pH}$ & $\begin{array}{l}\text { Initial } \\
\text { Temperature } \\
\left({ }^{\circ} \mathrm{C}\right)\end{array}$ \\
\hline 1 & Soya Milk (SM) & 12.8 & 72 \\
\hline 2 & Rice Water(RcW) & 12.3 & 62 \\
\hline 3 & Tea Decoction (TD) & 10.3 & 60 \\
\hline 4 & Gum kondagogu (GKg) & 10.2 & 60 \\
\hline 5 & Tulsi Leaves (TL) & 10.2 & 50 \\
\hline 6 & Soya Leaves (SL) & 10.1 & 60 \\
\hline 7 & Aloe Vera (AlV) & 10.1 & 59 \\
\hline 8 & Spinach Leaves (SpL) & 9.0 & 60 \\
\hline 9 & Rose Petals (RP) & 8.1 & 58 \\
\hline
\end{tabular}

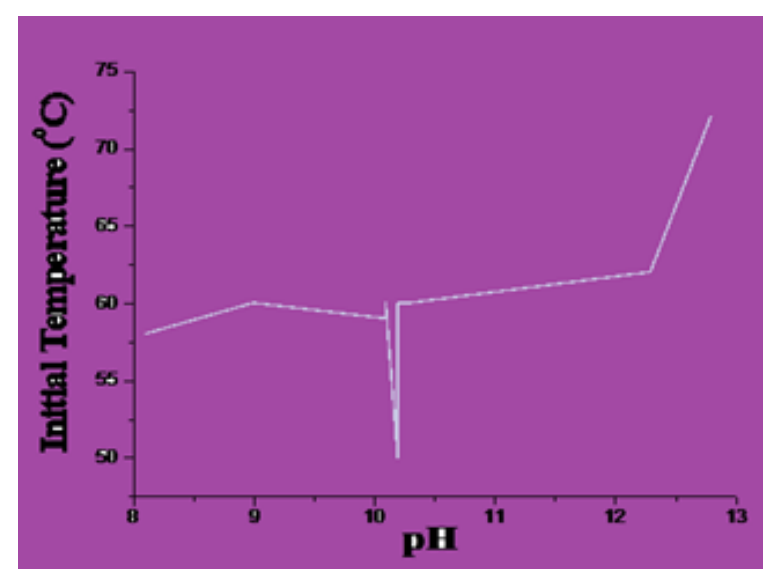

Figure 3 : Effect of NS on $\mathrm{pH}$ and initial Temperature

\subsection{Effect of NS on rate of reaction:}

Effect of NS on rate of reaction is dependent on relative NS's chemical activity. The reaction temperature depends largely on the chemical nature of the NS. The precipitation time to reach the room temperature is given in the Table 2. The time taken for the precipitate to settle down to room temperature is noted down as a measure of observation The reaction time at eight minutes, is the minimum in
Tulsi leaves and it is 9 minutes in SL. Time taken is maximum in RP, with 25 minutes.

Although there is difference in every natural stabiliser, the nano-HAP powders were in good agreement with XRD peaks. It is known to us, through literature, that the synthesised nano-HAP powders are good to use if their $\mathrm{Ca} / \mathrm{P}$ values are in between 1.65-185. In present case, it is observed that $\mathrm{SM}, \mathrm{RcW}$, SL and SpL are in good agreement for the same. Nano-HAP powders synthesised using TD, TL, Alv and RP are calcium efficient nano-HAP powders. Whereas, nano-HAP powder synthesised using GKg is calcium deficient. The graphical relation between Times versus $\mathrm{Ca} / \mathrm{P}$ is represented inFigure 3 .

Table 2: Effect of NS on reaction Time and $\mathrm{Ca} / \mathrm{P}$

\begin{tabular}{|l|l|l|l|}
\hline $\begin{array}{l}\text { S. } \\
\text { No. }\end{array}$ & NS at 15ml & $\begin{array}{l}\text { Time } \\
\text { (in } \\
\text { minutes) }\end{array}$ & Ca/P \\
\hline 1 & Soya Milk (SM) & 21 & 1.75 \\
\hline 2 & Rice Water(RcW) & 19 & 1.79 \\
\hline 3 & Tea Dicoction (TD) & 13 & 2.03 \\
\hline 4 & $\begin{array}{l}\text { Gum kondagogu } \\
\text { (GKg) }\end{array}$ & 16 & 1.55 \\
\hline 5 & Tulsi Leaves (TL) & 8 & 1.96 \\
\hline 6 & Soya Leaves (SL) & 9 & 1.85 \\
\hline 7 & Aloe Vera (Alv) & 13 & 1.98 \\
\hline 8 & Spinach Leaves(SpL) & 19 & 1.75 \\
\hline 9 & Rose Petals (RP) & 25 & 2.17 \\
\hline
\end{tabular}

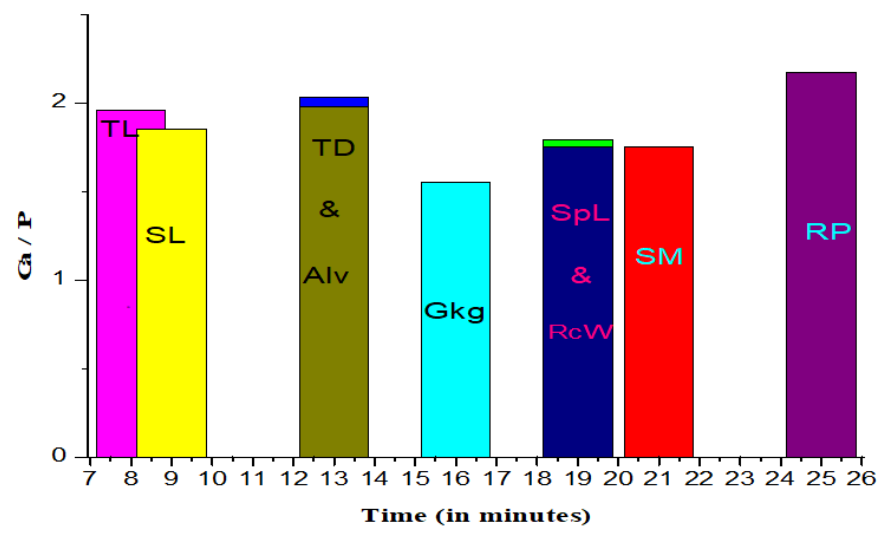

Figure 4 : Effect of NS on reaction Time vs.Ca/P 


\subsection{Energy Dispersive Spectroscopy - Effect of NS on $\mathrm{Ca} / \mathrm{P}$ :}

A surface analytical technique that is used for the elemental analysis or chemical characterisation, using $\mathrm{X}$-ray spectroscopy, is Energy Dispersive Spectroscopy (EDS). EDS allows the elemental composition of the nano-HAP to be measured. It also detects the presence of any residual materials or unwanted by-products present in the powders.

Synthetic Nano-HAP requires $\mathrm{Ca} / \mathrm{P}$ closer to or equal to 1.67. A number of NSs are employed during the synthesis of nano-HAP powders have resulted in different $\mathrm{Ca} / \mathrm{P}$ values. During the process the freshly prepared $15 \mathrm{ml}$ solution of each of the above discussed NSs are added slowly and the whole mixture is put on the magnetic stirrer to get the homogeneous precipitation.

It is possible to evenly coat porous implants with nano sized carbonated $\mathrm{HA}$ and other $\mathrm{Ca} / \mathrm{P}$ compounds, bio mimicking the bone mineralisation process, by immersing implants in SBF [36-38]. The nature of the $\mathrm{Ca} / \mathrm{P}$ coating, via its microstructure, its dissolution rate and its specific interaction with body fluids, can influence the osteogenecity of the coating as well as bone remodelling process $[39,40]$.

The Energy Dispersive Spectroscopic values depict the distribution of Calcium and Phosphorousof the nano-HAP powdersand are used to calculate $\mathrm{Ca} / \mathrm{P}$. The EDS results of nano-HAP powders are given in Table 3 and the spectra are given in the Figure 5 ((a)and (b)). It is observed that the $\mathrm{Ca} / \mathrm{P}$ ratio of samples prepared using RcW, SM, SL and SpL are within the acceptable range of synthesised nano-HAP i.e. 1.65-1.85 [41, 42]. Experimental results of literature indicate that the increase in initial $\mathrm{pH}$ value directly causes an increase in Ca / P [43-44].
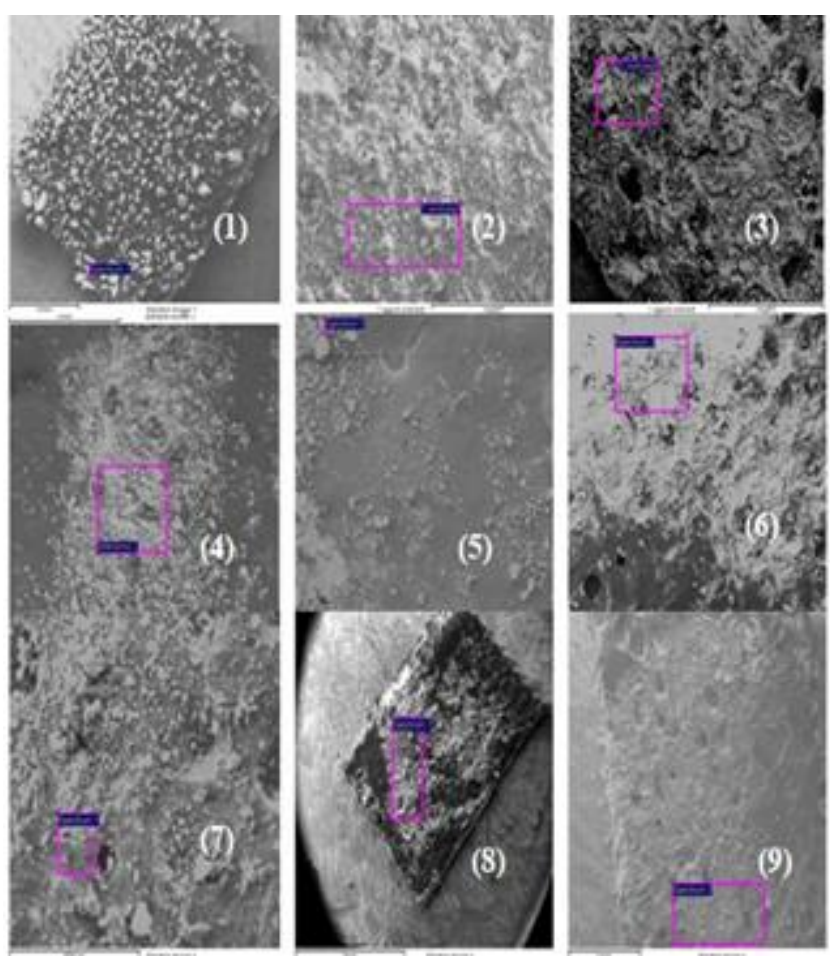

Figure 5(a): EDS spectra taken from the region marked by blue rectangle to see the effect of NS on

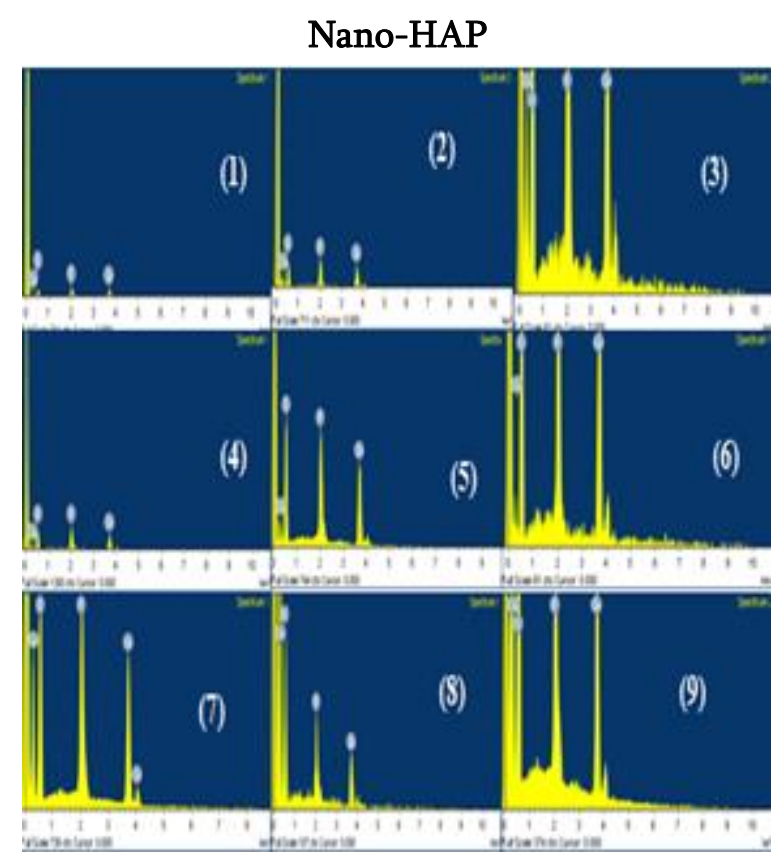

Figure 5(b): EDS Spectra of nano-HAP powders synthesised using NSs 
Table 3: Effect of NS on $\mathrm{Ca} / \mathrm{P}$

\begin{tabular}{|l|l|l|l|l|}
\hline $\begin{array}{l}\text { S. } \\
\text { No. }\end{array}$ & NS at 15ml & Ca & P & $\begin{array}{l}\text { Ca/ } \\
\mathrm{P}\end{array}$ \\
\hline 1 & Soya Milk (SM) & 37.24 & $\begin{array}{l}21.2 \\
3\end{array}$ & 1.75 \\
\hline 2 & $\begin{array}{l}\text { Rice } \\
\text { Water(RcW) }\end{array}$ & 35.28 & $\begin{array}{l}19.7 \\
1\end{array}$ & 1.79 \\
\hline 3 & $\begin{array}{l}\text { Tea Dicoction } \\
\text { (TD) }\end{array}$ & 39.42 & $\begin{array}{l}19.3 \\
9\end{array}$ & 2.03 \\
\hline 4 & $\begin{array}{l}\text { Gum kondagogu } \\
(\text { GKg) }\end{array}$ & 34.85 & $\begin{array}{l}22.4 \\
0\end{array}$ & 1.55 \\
\hline 5 & Tulsi Leaves (TL) & 34.20 & $\begin{array}{l}17.4 \\
4\end{array}$ & 1.96 \\
\hline 6 & Soya Leaves (SL) & 39.10 & $\begin{array}{l}21.1 \\
9\end{array}$ & 1.85 \\
\hline 7 & Aloe Vera (AlV) & 34.57 & $\begin{array}{l}17.4 \\
2\end{array}$ & 1.98 \\
\hline 8 & Spinach & 25.69 & $\begin{array}{l}14.6 \\
5\end{array}$ & 1.75 \\
\hline 9 & Leaves(SpL) & Rose Petals (RP) & 30.82 & $\begin{array}{l}14.1 \\
8\end{array}$ \\
\hline
\end{tabular}

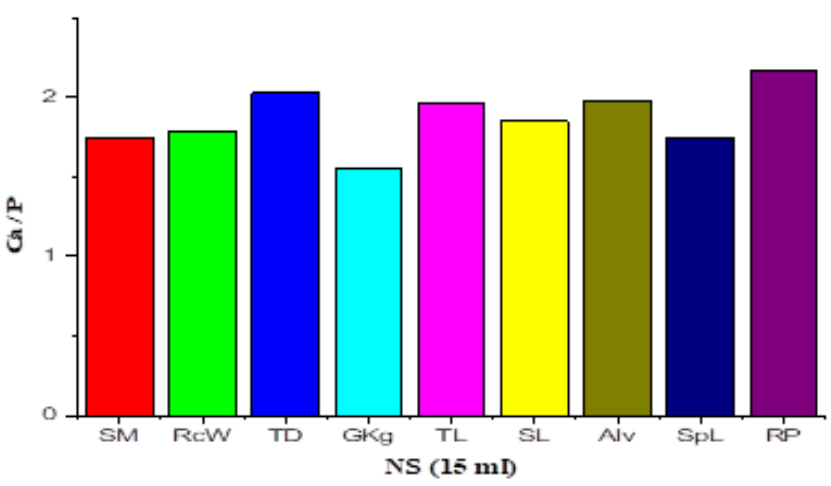

Figure 6: Effect of NS on reaction Time VsCa/P

\section{CONCLUSION}

Therefore, it is demonstrated that the $\mathrm{Ca} / \mathrm{P}, \mathrm{pH}$, time of reaction and initial temperature of the reaction are dependent on the NSs used and the conditions of preparation. However, the influence mechanism of initial temperature and relative NS used is too complex to build a model to explain it. Yet, this work has shown a way that there exists influence of NS in $\mathrm{Ca} / \mathrm{P}, \mathrm{pH}$, time of reaction and initial temperature of the reaction. This can be put into practice easily in $R$ $\& \mathrm{D}$ of the production and applications of nano-HAP.

\section{ACKNOWLEDGMENT}

Authors would like to thank Dr. Sathiraju Annapurna, Department of Physics, Koti Women's college Osmania University, Hyderabad, for several helpful discussions.

\section{REFERENCES}

[1]. Momma H, KaMita T, J. Mater.Sci. 22 (1987) 4247 4250.

[2]. Dorozhkin S.V, Spoke M, Angrew, Chem. Int. Ed Engl. 41 (2002) 3130-3146.

[3]. Zairin Noor 1, Volume 2013| Article ID 6790251| https://doi.org/10.1155/2013/679025

[4]. Ramachandra Rao R, Roopa H.N, Khannan T.S, J. Mater. Sci. Mater. Med. 8 (1997) 511-518.

[5]. Pramanik S., Agarwal A.K, Rai K.N, Garg A. Ceram. Int. 33 (2007) 460-466.

[6]. Bezzi G, Celotti G, Landi E, T.M.G. La Torretta, Sopyan I, Tampierri A, Mater.Chem. Phys. 78 (2003) 816-824.

[7]. W. Weng, G.Han, P. Du, G. Shen, Mater.Chem. Phys. 74 (2002) 92-97.

[8]. Wang Y.J, S.H. Zhang, K. Wei, N.R. Zhao, J.D. Chen, X.D. Wang, Mater. Lett. 60 (2006) 1484 1487.

[9]. Prelot B, T. Zemb, Mater. Sci. Eng. C 25 (2005) 553 559.

[10]. Loku.K, S. Yamauchi, H. Fujimori, S. Goto, M. Yoshimura, Solid State Ionics 151 (2002) 147 - 150.

[11]. Liu.J, Ye.X, H. Wang, M. Zhu, B.Wang, H. Yan, Ceram.Int. 121 (2002) 59-64.

[12]. Lim G.K, J. Wang, S.C. Ng, C. H. Chew, L. M. Gan, Biomaterials 18 (1997) 1433 - 1439.

[13]. Sun Y.X G.S. Guo, D.I. Tao, Z. H. Wang, J. Phys. Chem. Solids 68 (2007) 373 - 377.

[14]. Lim. G.J, Wang J, S.C. Ng, L.M. Gan, Langmuir 15 (1999) 7472 - 7477. 
[15]. Buyer E, Gitzhofer F, Boulos MI, J. Mater Sci Mater Med 2000; 11: 523-31.

[16]. Webster TJ, Siegel RW, Bizios R, Key Engineering Materials 2001; 192-5: 321-4.

[17]. Ferraz M.P, Monteiro F.J, Manuel C.M. Journal of Applied Biomaterials\& Biomechanics 2004; 2: 74-80.

[18]. Nimishakavi. S, V. Madhusudhan Rao, A.K. Singh, Adv. Mater. Lett. June 12, 2021, 12(7), 21071649 , DOI: 10.5185/amlett.2021.071649.

[19]. Masae Sakuma, Ayaka Suzuki, Minako Kikuchi and Hidekazu Arai, J Clin BiochemNutr. 2016 May; 62(3): 259-263. Published online 2018 Feb 17th, DOI: 10.3164/jcbn.17-79 PMCID: PMC5990409, PMID: 29892166.

[20]. Calvo MS, J Nutr.1993; 123: 1627- 1633.

[21]. Suchanek. W, Yoshimura. M , J Mater, 1998, 13.765.

[22]. Nimishakavi. S, V. Madhusudhan Rao, A.K. Singh, Adv. Mater. Lett. June 12, 2021, 12(3), 21031610, DOI: 10.5185/amlett.2021.031610.

[23]. Pahari Ghosh, Amar $\mathrm{Kr}$ Misra, Anup $\mathrm{Kr}$ Bhattacharya, NamrataTriveda, Arindam Ghosh, IpsitaGhosh, TapashRudra, Rakesh Roy \& Sanjay De. Published online: $02 \quad$ Oct 2017. https://doi.org/10.1080/09735070.2012.11886434

[24]. S. KalaignanaSelvi, V.T.P. Vinod, TanujaKosuri, D. Raju, R. Kusuma. Journal of Environmental Radioactivity 148 (2015) 33-41.

[25]. S. Bhaumik, S. D, Chowdury, M. H. Kabir and M. A. Ali. The Bangladesh Veterinarian (2008) 25(1): 3239.

[26]. SunitaVerma, J Phytophamacol 2016; 5(5): 205-207.

[27]. Journal of food science. 70(4): M 297- M215. DOI: 10.1111/J.1365-2621.2005.tb07190.X.

[28]. Routledge, 2005: CDs. Sir Ghillean Prance \&Mark Nesbitt, pp. 102-03.

[29]. Ethiopian journal of health sciences, 2014 Apr; 24(2): 139-144. PMCID: PMC4006208, PMID: 24795515, Copy right @ Jimma University Research \& Publications Office 2014

[30]. Nutrition Facts and Health Benifits -written by Kris Gunners. BSc on May 14th, 2019

[31]. Medically reviewed by Natalie Olsen, R.D.L.D. ACSMEP.C - written by Megan Ware. RDN.L.D. on June 29th, 2018.

[32]. Sonali Nanda, Pratyush Kumar Das, Centre of Biotechnology, O Anusandhan University,
Bhubaneswar, Odisha, India. Pharma Tutor (October-2015) Print -ISSN: 2394-6674, e-ISSN: 2347-7881 (Volume 3, Issue 10).

[33]. Sharma R. Medicinal plants of India, an Encyclopaedia. 2003, 215-217.

[34]. ISSN 2249-5738: Essential oil in the management of periodontal disease.

[35]. ISSN: 0975-4873 ijppr 216; 8(10); 1695-1697.

[36]. Barrere F, van der Valk CM, Dalmeijer RAJ, van Blitterswijk CA, de Groot K, Layrolle P. J Biomed Mater Res 2003; 64A: 378-87.

[37]. Barrere F, Layrolle P, van Blitterswijk CA, de Groot K, Bio ceramics 1999; 12: 125-8.

[38]. Habibovic P, Barrere F, Layrolle P, van Blitterswijk CA, de Groot K, Layrolle P. J Am Ceram Soc 2002; 85: 517-22.

[39]. Barrere F. J Biomed Mater Res 2003; 66A: 779-88.

[40]. Leeuwenburgh S, Layrolle P,Barrere $F$ et al. J Biomed Mater Res 2001; 56: 208 - 15. J Biomed Mater Res 2001; 56: 208-15.

[41]. Liu Y, Layrolle P, van Blitterswijk CA, de Groot K. J Biomed Mater Res 2001: 57: 327_35.

[42]. Wen HB, de Wijn JR, Li SH, et al. J Biomed Mater Res 1999; 46: 245-52.

[43]. Stigter M, de Groot K, Layrolle P. Biomaterials 2002; 23: 4143-53.

[44]. Piyapong Pankaew et al. Pattarinee White. J Nanosci.Nanotechnol.Jan 1; 20(1): 81-86, 2020. DOI: 10.1166/jnn.2020.17285.

\section{Cite this article as :}

Sreedevi Nimishakavi, V. Madhusudhan Rao, T. N. Aishwarya, A. K. Singh, "Green Chemistry Synthesis of Nano-Hydroxyapatite : Effect of Natural Stabilisers on $\mathrm{Ca} / \mathrm{P}$ ", International Journal of Scientific Research in Science, Engineering and Technology (IJSRSET), Online ISSN : 2394-4099, Print ISSN : 2395-1990, Volume 8 Issue 4, pp. 382-389, July-August 2021. Available at doi : https://doi.org/10.32628/IJSRSET218459 Journal URL : https://ijsrset.com/IJSRSET218459 